\title{
AN EVALUATION OF STRATEGIC ALLIANCES IN LINER SHIPPING-AN EMPIRICAL STUDY OF CKYH
}

\author{
Hua-An Lu \\ James Cheng \\ Business Division-Asia Service Department, Yang Ming Marine Transport Corporation. \\ Tai-Shen Lee \\ Department of Transportation Techniques, National Taiwan Ocean University.
}

Department of Shipping and Transportation Management, National Taiwan Ocean University., halu@mail.ntou.edu.tw

Follow this and additional works at: https://jmstt.ntou.edu.tw/journal

Part of the Business Commons

\section{Recommended Citation}

Lu, Hua-An; Cheng, James; and Lee, Tai-Shen (2006) "AN EVALUATION OF STRATEGIC ALLIANCES IN LINER SHIPPING-AN EMPIRICAL STUDY OF CKYH," Journal of Marine Science and Technology: Vol. 14: Iss. 4, Article 11. DOI: $10.51400 / 2709-6998.2090$

Available at: https://jmstt.ntou.edu.tw/journal/vol14/iss4/11

This Research Article is brought to you for free and open access by Journal of Marine Science and Technology. It has been accepted for inclusion in Journal of Marine Science and Technology by an authorized editor of Journal of Marine Science and Technology. 


\section{AN EVALUATION OF STRATEGIC ALLIANCES IN LINER SHIPPING-AN EMPIRICAL}

STUDY OF CKYH

\section{Acknowledgements}

The authors express their sincere gratitude to those professionals from Yang Ming Marine Transport Company, as well as anonymous experts from COSCO, K-Line, and Hanjin for contributing their valuable time and opinions to this study. 


\title{
AN EVALUATION OF STRATEGIC ALLIANCES IN LINER SHIPPING-AN EMPIRICAL STUDY $\mathrm{OF} \mathrm{CKYH}$
}

\author{
Hua-An Lu*, James Cheng**, Tai-Shen Lee***
}

Key words: strategic alliance, CKYH, Delphi method.

\begin{abstract}
The activities of alliances between liner carriers have increased intensively since the last decade, satisfying a whole new requirement of shippers stemmed from the industrial globalization. The development of strategic alliances is very important to the liner industry, especially based on a perspective of the booming market-Asia. For finding co-operative niches, possible disadvantages, successful factors, and the future development of the alliance co-operation, the investigation in this paper focused on members of the $\mathrm{CKYH}$, a potential strategic alliance group with four major carriers in Asia. We employed the Delphi method to conduct two rounds of survey for procuring the consensus opinions of participants among these four companies. Their responses reveal that strategic alliances have become an essential tool for large carriers to extend their service ranges in the global markets. Mutual trust between partners is a cornerstone to ensure the success of alliances, and this tendency will continue to develop for supporting the global requirement of the maritime logistic system.
\end{abstract}

\section{INTRODUCTION}

The formal formation of strategic alliances with global services in the liner shipping industry can be traced to the origin of the first generation at the end of 1995. Their developments have significantly impacted the supply capacities and the co-operative activities of this industry for many years. The most obvious phenomena not only took place on the horizontal share of fleet and route services [12], but also appeared on the vertical integration of port and inland transport operations $[11,4]$. Concrete actions, such as joint fleet, slot exchange, slot charter, slot purchase, share of port

Paper Submitted 12/14/05, Accepted 04/28/06. Author for Correspondence: Hua-An Lu.E-mail: halu@mail.ntou.edu.tw.

*Department of Shipping and Transportation Management, National Taiwan Ocean University.

**Business Division-Asia Service Department, Yang Ming Marine Transport Corporation.

***Department of Transportation Techniques, National Taiwan Ocean University. usage etc., have been widely operated in the contemporary liner operations. These steps were not just limited within the members of a specific strategic alliance group, and participants did not focus only on the global markets. A single loop of services might be possibly adopted alliance for stabilizing the prices of local markets, and the former competitors in the same service even became their co-operative objects. Strategic alliances, which are regarded as one method of strategic co-operation in this study, had been the source of allied powers. Even the strongest carrier can hardly confront their developments alone to survive in the liner industry [3].

In the beginning stage, global strategic alliances encountered an unstable process on the members of groups. According to an observation of Midoro and Pitto [9], organizational complexity and intra-alliance competition were the main driving factors to yield this high degree of instabilities. Ryan [13] dealt with the evolution of container shipping networks over a tenyear span from 1989 to 1999. Slack et al. [16] examined the development of strategic alliances from the transformation of services, the evolution of the fleet, and the adjustments made to the ports of call. Some changes were significant, such as the spread and intensification of services and the deployment of the largest vessels on alliance routes. These results revealed that the greater standardization was imposed in this industry from strategic alliances. Kadar [6] submitted a simple theory, one plus one creates more than double effectiveness, to explain the purpose of the alliance. Members of alliances would like to effectively reduce costs and increase the freight revenues, and to enjoy economies of scale by sharing resources with other partners but without investing any more capital. The characteristics of a successful alliance can be categorized as selecting the right partners, keeping a clear alliance structure, and emphasizing the process of ganging up. However, Alix et al. [1] made a different report for another growth ways of container shipping industry with the acquisition case of the Canadian Pacific (CP), which showed a special case that strategic alliance was not the only way 
to successfully survive.

In comparison with the style of consortia, which was controlled by the European carriers from 1960 to 1980 , this tendency of strategic alliances was evidently guided and pushed by the Asian carriers. Pushing energies came from that shipping companies had to follow the steps of their global scale customers, and to provide viable solutions to their extended markets transported from Asia. According to the report of the Containerization International in 2003, the throughput of the whole Asia containers shared $48.2 \%$ of the global market. The so-called "China effect" brought an essential energy of trading. The developments of those carriers based near by mainland China were relatively noticed. Thanopoulou et al. [18] reviewed that the history of the Korean shipping became a major player in the liner industry at the end of the last century. Ryoo and Thanopoulou [14] made a survey for motivations and successful reasons of various co-operative ways to the major Korean-operated carriers. Their research revealed that increasing market share and box utilization, maximizing operational synergy, and rationalizing service routes were ranked as the most prominent motives. Meanwhile, the successful reasons were the continuously mutual commitment of facilities and mutual agreement on co-operative objectives.

Several studies were devoted on the observation of strategic alliances from various perspectives. To date, however, no research has investigated the opinions of experts who have ever participated in planning and executing of alliance agreements within one alliance group. The purpose of this investigation is to explore the motivation, possible advantages, successful factors, and the future development of strategic alliances within a specific alliance group. It is valuable to realize the experience of leading strategic alliances or mega groups for academic researchers and practitioners, as their decision will dominate the future development in the liner industry. Nevertheless, those experienced experts are hardly to be known to execute the academic interviews. Through the assistance of one member of an alliance group-the $\mathrm{CKYH}$, we attempt to employ the Delphi method for conducting few experts' surveys in this research.

\section{STRATEGIC ALLIANCE OF THE CKYH}

The CKYH consists of four famous carriers, i.e. COSCO in China, K-Line in Japan, Yang Ming in Taiwan, and Hanjin in South Korea. In 1996, this alliance started a specific co-operation with slot charter and exchange on ocean going services between K-Line, Yang Ming, and COSCO. Gradually, they had joint fleet agreement on the main services before the end of the last century. Hanjin formally participated in this group until year 2000, although Yang Ming and Hanjin already had an agreement of slot charter on the service from Asia to the USA east since 1991. Needless to say in Asia, these four carriers ranked among the top 20 companies by slot capacities in the global liner industry. Table 1 shows the status of their slot capacities in 2004, and we can still find this group forming two significant clusters, i.e. Hanjin/COSCO and K-Line/Yang Ming.

Although members of this group had their own paces of advancing, they all accelerated their expansions after year 2000 (see Figure 1). We cannot thoroughly ascribe the reason to their alliance, since at the same time size enlargement of container ships was also a main tendency. However, the fruitful returns of strategic alliances definitely encouraged them to bravely increase service tonnages.

The CKYH alliance together with the other four alliances or mega carriers totally shared $45 \%$ of global

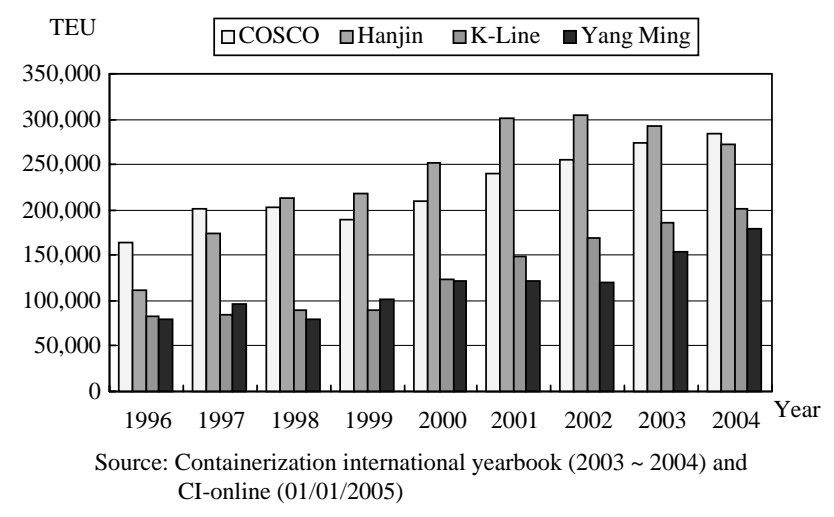

Fig. 1. Capacities of members in CKYH from year 1996 to 2004.

Table 1. Top 10 carriers for the slot capacities within Asia in 2004

\begin{tabular}{lcccccccccc}
\hline \multicolumn{1}{c}{ Asian rank } & 1 & 2 & 3 & 4 & 5 & 6 & 7 & 8 & 9 & 10 \\
\hline Carrier & Evergreen & APL & COSCO & Hanjin & CSCL & NYK & OOCL & MOL & K-Line & Y. M. \\
Capacity (TEUs) & 348,087 & 307,094 & 284,737 & 271,644 & 247,996 & 243,339 & 218,667 & 213,141 & 200,555 & 178,675 \\
\% of global capacity & 5.3 & 3.3 & 3.3 & 3.5 & 1.7 & 2.8 & 2.2 & 2.7 & 2.2 & 1.8 \\
Global rank & 5 & 6 & 7 & 8 & 9 & 10 & 11 & 12 & 13 & 16 \\
\hline
\end{tabular}

Source: Compiled from containerization international-online (01/01/2005) 
capacities in 2004. As shown in Figure 2, the Grand alliance, which includes P\&O Nedlloyd, Hapag Lloyd, OOCL, NYK, and NYSC, occupied $12.2 \%$ of market share to be the largest group of the liner industry. Behind the CKYH, Maersk Sealand plus Portlink and Safmarine ranked as the third position with $10.2 \%$. The TNWA alliance, which consists of APL, Hyundai, and MOL, also owned $7.3 \%$ of the global slots. The Evergreen Marine Company (EMC) plus their stock holding companies, Hatsu Marine and Lloyd Trienstino, shared $5.0 \%$ of global capacities.

Some Asian carriers have also joined other global strategic alliances except members of the CKYH group (see Table 2). However, only one specific alliance group was considered in this research. The reasons why we selected the CKYH alliance are as follows.

1. The CKYH alliance is the latest one to be formed, and its members have never left. They should have many coordination experiences on business and operation handlings.

2. Members of this alliance are all Asian carriers with the similar background on the managing culture.

3. The entire capacity of this alliance ranks at number two with $10.3 \%$ of supplied slots in the world. They have certain potential to influence the tendency of the future development in this industry.

4. The number of members in this alliance is more than

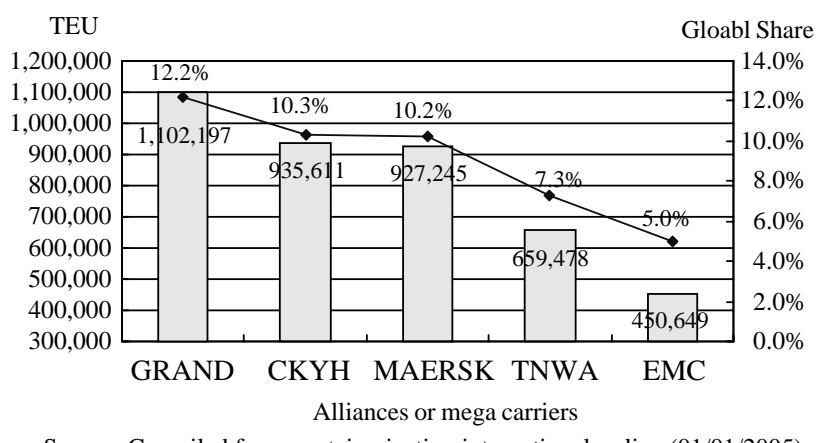

Source: Compiled from containerization international-online (01/01/2005)

Fig. 2. Capacities and shares of five main alliances or mega carriers in 2004. two companies, but this alliance is relatively more stable than others in view of historical exhibition.

\section{METHODOLOGY}

Researchers have applied the Delphi method, a popular and long-range technique, to a wide variety of situations as a tool for expert judgment for a long time, especially in the field of qualitative forecasting [5]. Linstone and Turoff [7] presented a definition of the Delphi technique as a method for structuring a group communication process, which can be effective in allowing a group of individuals to deal with a complex problem. A key advantage of the Delphi technique is that it avoids direct confrontation of the experts. Some issues have already developed with this approach, such as exposing priorities of personal values and social goals, distinguishing and clarifying perceived motivations, developing causal relationships in complex economic or social phenomena, exploring planning options, and gathering data etc.

The Delphi method has also been applied to identify and prioritize issues for managerial decision-making in information systems. Schmidt [15] presented a methodology based on nonparametric statistical techniques to conduct ranking-type Delphi surveys. Okoli and Pawlowski [10] contributed some guidelines for the process of selecting the appropriate experts, and presented detailed principles for making design choices during the process to ensure a valid study. They classified the application of the Delphi method into two parts: forecasting and issue identification/prioritization, and concept/framework development. To reach the consensus viewpoints of participants within a specific field, this approach conducts surveys repeatedly based on a feedback of analysis results of the last round.

In the trade and transportation fields, the Delphi techniques have been applied to the forecasting of future global trade and business [2], transportation policy [8], land use impact of transportation plan [17] and political risk assessment of international ports [19]. As to this research, some properties are similar as the

Table 2. Members of the top five strategic alliances and mega carriers in 2004

\begin{tabular}{|c|c|c|c|c|c|c|c|c|c|}
\hline \multicolumn{10}{|c|}{ StrategicCountries and carriers } \\
\hline Alliances & Denmark & British & Germany & Japan & China & Hong Kong & Taiwan & South Korea & Singapore \\
\hline GRAND & & P\&O NL & Hapag LL & NYK & & OOCL & & & \\
\hline CKYH & & & & K-Line & $\mathrm{COSCO}$ & & Y. M. & Hanjin & \\
\hline TNWA & & & & MOL & & & & Hyundai & APL \\
\hline Maersk & Maresk & & & & & & & & \\
\hline EMC & Sealand & & & & & & Everoree & & \\
\hline
\end{tabular}


Table 3. Ranges of mean for four parts of survey

\begin{tabular}{|c|c|c|c|c|}
\hline \multirow{2}{*}{ Part } & \multirow{2}{*}{$\begin{array}{c}\text { Number } \\
\text { of } \\
\text { questions }\end{array}$} & \multicolumn{3}{|c|}{$\begin{array}{c}\text { Scale } \\
\text { (Ranges of mean) }\end{array}$} \\
\hline & & $\begin{array}{c}1 \\
(1.0 \sim 1.6) \\
\end{array}$ & $\begin{array}{c}2 \\
(1.7 \sim 2.3) \\
\end{array}$ & $\begin{array}{c}3 \\
(2.4 \sim 3.0) \\
\end{array}$ \\
\hline I & 20 & not important at all & important & very important \\
\hline II & 10 & not disadvantageous at all & disadvantageous & very disadvantageous \\
\hline III & 15 & not important at all & important & very important \\
\hline IV & 10 & disagreed & agreed & totally agreed \\
\hline
\end{tabular}

application that led to the need for employing Delphi as Linstone and Turoff [7] mentioned. The strategic concept and development of liner carriers are difficult to lend to precise analytical techniques. We were going to investigate the experience within a small decision group, but their members possess diverse backgrounds with respect to the managing culture. Although these four companies are partners of a same strategic alliance, to discuss the experience led to a successful co-operation may need an anonymous communication process in order to sufficiently presenting their opinions.

The Delphi method applied in our study is based on a questionnaire with four parts as follows.

(a) Part I: key reasons for strategic co-operation.

(b) Part II: possible disadvantages during co-operation.

(c) Part III: key reasons for successful co-operation.

(d) Part IV: prediction of middle-term future for global liner shipping industry.

We designed 20,10,15, and 10 questions for each part respectively, and the whole content of the questionnaire is listed in the appendix. Each one of questions gives respondents three scales to reflect their opinions on the levels of importance, disadvantage, or agreement to its description (see Table 3). We give one, two or three points for these three scales when each is selected. The average scores for one question, i.e. its mean, should fall into the range between 1.0 and 3.0. We then divide this range into three parts in average to represent the degree of approaching the scale because too small range may increase the investigated iterations for reaching the consensus. The same width of standard ranges for every scale counted to 1 decimal fraction can make the equivalent chance of the mean falling into each scale in the numerical calculation. For judging whether or not a question reached a desired level of consensus, we define the recognition of a question as the percentage of experts whose answers are same as the scale of this question mean. For example, the mean of all experts' scores is between 1.7 and 2.3, i.e. the range of scale, for a certain question. Its recognition will be considered as $60 \%$ when there are $60 \%$ of reviewers choosing scale 2 as their answers. The meaning of recognition is similar to a given standard range to represent the concentration level of the mean which must have enough individuals that contributed the same opinion. If too few individuals select the scale as same as the mean of all participants, then the recognition will not be accepted. This treatment can avoid many extreme responses to affect the real consensus. The important thing will then be deciding the standard of the recognition threshold. The authors decided to adopt a high level recognition for each question- $80 \%$. That means one question needs $80 \%$ of reviewers to choose the same scale and to be same as the scale of the total mean. This high threshold can also avoid the possible influence of the extreme values. Furthermore, the criteria of survey termination are the number of questions that reached the threshold of $80 \%$ must be over half of total, i.e. more than 28 questions.

We did not have too many choices in selecting the investigated individuals, for the goal of this research already focused on a specific strategy alliance group. Staffs or local representatives of liner companies might feel the importance of strategic alliances, but they might not sufficiently understand the details of the co-operative construction. The experts who participated in planning or executing the relative affairs were our only candidates. In view of the consideration that the investigated persons must completely understand the entire decisions of their own companies, the majority of them were in charge of managing strategies. Thus, the final panel includes 14 experts-8 people from Yang Ming and 2 people from each of the other three companies. These specialists are at least the managers in their major fields, and played the window roles coordinated with partners in planning, finance, or operation divisions. It is evident that the panel includes more experts from Yang Ming, because the headquarters of Yang Ming is located in Taiwan. This allowed us to easily procure their inner organizational structure and contact the real candidates in this company. Meanwhile, we need the assistance of Yang Ming to filter candidates of other 
Table 4. Experts participated in the investigation process

\begin{tabular}{lcccccc}
\hline \multicolumn{2}{c}{ Company } & \multicolumn{2}{c}{$1^{\text {st }}$ round of survey } & \multicolumn{2}{c}{$2^{\text {nd }}$ round of survey } & \multirow{2}{*}{ Division of experts } \\
\cline { 3 - 6 } & & Expected & Actual & Expected & Actual & \\
\hline COSCO & $(\mathrm{C})$ & 2 & 1 & 1 & 1 & Planning \\
K-Line & $(\mathrm{K})$ & 2 & 1 & 1 & 1 & Planning \\
Yang Ming & $(\mathrm{Y})$ & 8 & 8 & 8 & 8 & Planning, operation, \\
Hanjin & $(\mathrm{H})$ & 2 & 1 & 1 & 0 & Finance, business \\
Total & & 14 & 11 & 11 & 10 & Planning \\
\hline
\end{tabular}

Table 5. Recognition distribution within two rounds of survey

\begin{tabular}{|c|c|c|c|c|c|}
\hline \multirow{2}{*}{$\begin{array}{c}\text { Recognition } \\
\text { (above) }\end{array}$} & \multicolumn{2}{|c|}{$1^{\text {st }}$ round of survey } & \multicolumn{2}{|c|}{$2^{\text {nd }}$ round of survey } & \multirow{2}{*}{$\begin{array}{l}\text { Increasing \% } \\
\text { in processing }\end{array}$} \\
\hline & \# of questions & $\%$ of total & \# of questions & $\%$ of total & \\
\hline $50 \%$ & 42 & 76.4 & 55 & 100.0 & 23.6 \\
\hline $60 \%$ & 31 & 56.4 & 47 & 85.5 & 29.1 \\
\hline $70 \%$ & 20 & 36.4 & 43 & 78.2 & 41.8 \\
\hline $80 \%$ & 7 & 12.7 & 38 & 69.1 & 56.4 \\
\hline $90 \%$ & 0 & 0.0 & 23 & 41.8 & 41.8 \\
\hline $100 \%$ & 0 & 0.0 & 9 & 16.4 & 16.4 \\
\hline
\end{tabular}

companies, and to inquiry their willingness of participating surveys. This unavoidable situation and the role of Yang Ming resulted in restricting the possibilities to invite more experts of other three companies.

We conducted the survey from the end of 2003 to the first season of 2004. The questionnaires were sent to the experts who served in their own respective headquarters by e-mail. In the first round, we received 11 responses from all of experts because the three liners, except Yang Ming, insisted on returning only one copy of questionnaire to present the unique opinions on behalf of their own companies. In the second round, 11 respondents received our analysis results of the first round and were asked to reflect the opinions for the same questionnaire. During this round, one of those three companies which replied one copy in the first survey strongly refused to response again, for they had already presented their opinions clearly and completely. After analyzing the 10 copies of return questionnaire, the results met the terminated conditions already. A summary of response status for each round of the study is presented in Table 4.

\section{RESULTS AND DISCUSSIONS}

The percentage of questions with recognition over $80 \%$ is below $50 \%$ in the first round, while 38 out of the 55 questions with recognition over $80 \%$, i.e. $69.1 \%$, appeared in the next one. The threshold of survey termination has been met in the second round already. Table 5 lists the distribution for accumulative percentages of recognitions for two rounds of investigation. The final results reveal that part III has the highest percentage of $87 \%$ among four parts. Part I receives $65 \%$, while other two parts reach to $60 \%$. In total, 22 questions, which are $40 \%$ of all 55 questions, fall into the middle level of importance. Responses that belonged to low and high scales are all less than 10 questions as shown in Table 6. We describe their contents in detail and discuss our findings as follows.

\section{Key reasons for strategic co-operation}

In this part, to extend service coverage and to provide more frequencies are reflected to be the most important motivations of adopting strategic alliances. Questions with middle level of importance include operational and financial concerns, such as providing faster transit service, faster entrance to new markets and sharing risks for this action, maximizing operational synergy, increasing capital utilization of equipments, and reducing investment burden on equipments. However, experts express that the factors relative to stabilizing the freight rate of markets, accommodating the government policy, gaining the precise skill or know-how of this industry and reducing the pressure of competition are not so important at all (see Table 7).

These results reveal that the motivations of mem- 
Table 6. The number and percentage of questions that reached the consensus

\begin{tabular}{cccc}
\hline & \multicolumn{3}{c}{ Scale-Level of responses } \\
\cline { 2 - 4 } Part & 1-Low & 2-Middle & 3-High \\
& $(1.0 \leq$ Mean $\leq 1.6)$ & $(1.7 \leq$ Mean $\leq 2.3)$ & $(2.4 \leq$ Mean $\leq 3.0)$ \\
\hline I & $5(25 \%)$ & $6(30 \%)$ & $2(10 \%)$ \\
II & $1(10 \%)$ & $5(50 \%)$ & $0(0 \%)$ \\
III & $2(13 \%)$ & $10(67 \%)$ & $1(7 \%)$ \\
IV & $1(10 \%)$ & $1(10 \%)$ & $4(40 \%)$ \\
\hline
\end{tabular}

Table 7. Key reasons of strategic alliances in liner shipping

\begin{tabular}{rlcc}
\hline \multirow{2}{*}{ No. } & \multicolumn{1}{c}{ Questions } & \multicolumn{2}{c}{$\begin{array}{c}2^{\text {nd }} \text { round } \\
\text { of survey }\end{array}$} \\
\cline { 3 - 4 } & & Mean & Recog. \\
\hline 5 & Extend service coverage & 2.7 & $80 \%$ \\
7 & Provide more frequent sailing services & 2.7 & $80 \%$ \\
8 & Faster entry to new trade routes & 2.2 & $80 \%$ \\
2 & Share the risks of providing new liner services & 2.1 & $90 \%$ \\
14 & Maximize operational synergy & 2.0 & $100 \%$ \\
3 & Increase capital utilization of ships, container equipment \& terminal facility & 1.9 & $90 \%$ \\
19 & Reduce financial burden on equipment investment & 1.9 & $90 \%$ \\
12 & Provide faster transit service & 1.8 & $80 \%$ \\
15 & Stabilize freight rate & 1.2 & $80 \%$ \\
4 & Conform to shipping policy of foreign government & 1.1 & $90 \%$ \\
13 & Gain the skill or know-how in liner shipping industry & 1.1 & $90 \%$ \\
18 & Limit external competition & 1.1 & $90 \%$ \\
20 & Conform to shipping policy of national government & 1.1 & $90 \%$ \\
\hline
\end{tabular}

Note: 1 . Cited questions with recognition above $80 \%$.

2. Level of responses: $1=$ not important at all, $2=$ important, $3=$ very important.

bers in the studied group for participating strategic alliances are focused on the consideration of business development to provide their customers more and extensive services. Operational or financial matters are not the main reasons to develop global strategic alliance or to form a stable co-operation. In comparison with the earlier study [14], these answers do not entirely disclose the equal evaluation of their investigated liner practitioners. In addition, the co-operation of this group does not aim to dominate the freight price as the consortia, or to defend the competition from other liners or alliances. Their intension is to meet some inner expectation in their own development, not to learn more skills from external sources or even to follow government policy. The real co-operative niches are to promote themselves to another level of services. Cost reduction and financial investments, which large companies can afford and may consider as a necessary expenditure, are not the prominent concerns to them.

\section{Possible disadvantages during co-operation}

There is no question to be evaluated as having the ultimate disadvantages in this part, but the market competition among partners may cause a bit of worry to these experts as shown in Table 8. The compatibility and market reputation of partners also bring the middle level of the anxiety for the respondents. As well as the inherent instability between partners and the decision making procedure within the alliance possibly become the barriers of their communication. The possibilities to be merged or acquired by other partners cannot affect the relationships among the members.

Members of the studied group sufficiently presented their faith to their co-operative relationships from the answers in this part. They have a firm confidence that they will not be merged or acquired by their partners in the alliance. However, they seem only worry little about both the external and internal possible disadvantages of alliances. The former includes business 
Table 8. Possible disadvantages of strategic co-operation in liner shipping

\begin{tabular}{clrr}
\hline \multirow{2}{*}{ No. } & & \multicolumn{1}{c}{ Questions } & \multicolumn{2}{c}{$\begin{array}{c}2^{\text {nd }} \text { round } \\
\text { of survey }\end{array}$} \\
\cline { 3 - 4 } & & Mean & Recog. \\
\hline 1 & Market competition between co-operating partners & 2.0 & $100 \%$ \\
6 & Infeasibility to co-operate due to partners' compatibility & 1.9 & $90 \%$ \\
2 & Inherent instability between co-operating partners & 1.8 & $80 \%$ \\
4 & Inefficient decision-making procedure within co-operation partners & 1.8 & $80 \%$ \\
9 & Market reputation may be affected negatively due to co-operate with & 1.8 & $80 \%$ \\
& poor-reputed partner & 1.1 & $90 \%$ \\
\hline
\end{tabular}

Note: 1 . Cited questions with recognition above $80 \%$.

2. Level of responses: $1=$ not disadvantageous at all, $2=$ disadvantageous, $3=$ very disadvantageous.

Table 9. Key reasons of successful co-operation in liner shipping

\begin{tabular}{|c|c|c|c|}
\hline \multirow[t]{2}{*}{ No. } & \multirow[t]{2}{*}{ Questions } & \multicolumn{2}{|c|}{$\begin{array}{l}2^{\text {nd }} \text { round } \\
\text { of survey }\end{array}$} \\
\hline & & Mean & Recog. \\
\hline 15 & Mutual trust between all partners & 3.0 & $100 \%$ \\
\hline 13 & The number $\&$ size of partners & 2.2 & $80 \%$ \\
\hline 11 & Partner compatibility (in particular of company’s culture) & 2.1 & $90 \%$ \\
\hline 14 & A reasonable \& practicable cooperating rule for following up & 2.1 & $90 \%$ \\
\hline 1 & Continuous mutual commitment of facilities (ships, equipment) & 2.0 & $100 \%$ \\
\hline 2 & Mutual agreement on co-operation objectives & 2.0 & $100 \%$ \\
\hline 3 & Good understanding by all parties of competition and marketplace & 2.0 & $100 \%$ \\
\hline 7 & Compatible decision-making processes & 2.0 & $100 \%$ \\
\hline 9 & Open communication between the parties & 2.0 & $100 \%$ \\
\hline 6 & Good interpeopleal relations between partner & 2.0 & $80 \%$ \\
\hline 10 & Continuous CEO direction and involvement & 1.9 & $90 \%$ \\
\hline 8 & Sharing of integrated computer systems/EDI & 1.3 & $80 \%$ \\
\hline 4 & Continuous mutual commitment of finance & 1.1 & $90 \%$ \\
\hline
\end{tabular}

Note: 1 . Cited questions with recognition above $80 \%$.

2. Level of responses: $1=$ not important at all, $2=$ important, $3=$ very important..

scope, i.e. market competition and reputation of partners, while the latter comprises of partners' compatibility, inherent instability, and inefficient decision-making procedure. These interior causes are mostly similar with the earlier observation in Midoro and Pitto [9]. We estimate these conflicts to have significantly taken place in the process of their co-operation, but they may have accumulated too much experience on inner discussion and practical operation to construct an acceptable implemented model. These attainments are not easily destroyed.

\section{Key reasons for successful co-operation}

All of the experts believe that to build mutual trust between partners is the most important qualification for forming a successful co-operation, so this condition acquired the overall recognition as shown in Table 9. Several dimensions are also considered important. First, the number of members affects the construction of the group, and the candidates of co-operative partners must be seriously selected from their sizes and compatibilities for each other. Second, the co-operative objective under mutual agreement and continuous commitment of facilities needs to be assured. Then, communication techniques such as following a reasonable and practicable rule, achieving a good understanding for the competition, keeping open communication at the compatible decision-making processes, and acquiring the direction and involvement from companies' CEO also fall into this level of importance. Nevertheless, individualized assets regarding information system and fi- 
Table 10. Middle-term future development of strategic alliances in liner shipping

\begin{tabular}{|c|c|c|c|}
\hline \multirow[t]{2}{*}{ No. } & \multirow[t]{2}{*}{ Questions } & \multicolumn{2}{|c|}{$\begin{array}{l}2^{\text {nd }} \text { round } \\
\text { of survey }\end{array}$} \\
\hline & & Mean & Recog. \\
\hline 1 & $\begin{array}{l}\text { The strategic co-operation in global liner shipping will be continually developing } \\
\text { to enable the carrier responding the rapid change of liner shipping industry }\end{array}$ & 3.0 & $100 \%$ \\
\hline 2 & $\begin{array}{l}\text { The strategic co-operation among liner shipping carriers will become more important } \\
\text { than before as today's liner shipping industry is hardly to survive by individual alone }\end{array}$ & 2.8 & $80 \%$ \\
\hline 6 & $\begin{array}{l}\text { Total logistics solution (One-Stop-Shopping) will be the main stream of global shipper's } \\
\text { requirement and the liner carrier's strategic co-operations on terminal and inland } \\
\text { assets will be increased }\end{array}$ & 2.8 & $80 \%$ \\
\hline 10 & $\begin{array}{l}\text { In addition to major East-west routes, the Intra Asian regional container trades is } \\
\text { growing up significantly }\end{array}$ & 2.8 & $80 \%$ \\
\hline 4 & $\begin{array}{l}\text { The purpose \& model of strategic co-operation will become more \& more flexible to } \\
\text { enable the liner carrier to meet the requirement of quick-changing shipping environment }\end{array}$ & 2.1 & $90 \%$ \\
\hline 8 & $\begin{array}{l}\text { To use the chartered vessels instead of own purchasing vessels will be increased in } \\
\text { order to reduce both the capital expenditure \& risk }\end{array}$ & 1.2 & $80 \%$ \\
\hline
\end{tabular}

Note: 1 . Cited questions with recognition above $80 \%$.

2. Level of responses: 1 = disagreed, 2 = agreed, $3=$ totally agreed.

nancial commitment are not the main reasons of successful alliance at all.

The strong agreement and recognition on mutual trust between partners can explain the core value of successful alliances. A stable alliance indeed requires members devoting themselves into multiple linkages to ensure successful on each issue for accumulating abundance of co-operative achievements. The concrete actions include the flexibility of co-operation, compatible decision-making processes, and open communication.

\section{Future development of alliances}

In this part, there are none of the questions in which recognition is over the threshold in the first round of survey, but experts broadly adjust their selection in the second one. Without cause, they recognize strategic alliances will continuously develop not only to respond the changing tendency but also to survive in this industry. They also agree the logistic integration and booming trades of the intra-Asia may stimulate carriers to adapt more flexible alliance activities. However, liner companies will not entirely use chartering tonnages to replace their own fleet investment (see Table 10).

To view the future development, all experts highly recognized that global strategic alliance would continue to exist in the liner industry. Alliances may not be the only way but a successful method to confront the rapidly changing environment and to follow the wider industrial globalization activities. Vertical integration in the transit process of containers, i.e. sufficiently connect the terminal and inland network for each other, can provide customers total logistic services for reaching the requirement of one-stop-shopping. In the near future, it is without a doubt that Asia will be totally connected with the main stream of the global international trades. Asian carriers will play a more important role in the advanced liner shipping industry.

\section{CONCLUSION}

Strategic alliances between liner shipping companies provide a whole new stage along with a flexible managing method for the Asian carriers. They not only adopt this approach to adjust the aims of future development, but also efficiently adapt themselves to the effectively operational model. This study implemented an investigation to a specific strategic alliance group, CKYH, for exploring the development of global liner services by the Delphi method. We conclude our findings from the CKYH survey:

1. The business niches, to extend the service coverage and to provide more service frequencies, are more important than other factors relative to the operational and financial aids. The motivations for rationalization of service routes and enjoying economies of scale also emphasize the same consideration.

2. Mutual trust is the most important basis for a successful strategic alliance, but members still need to ensure the co-operative objectives and to be familiar with the managing culture of partners through each opportunity in the open communication processes. 
3. As for the future development of strategic alliances, all of the experts agree that it is still the main stream of the liner industry. Carriers will follow the tendency of international trades, especially on the integration of global logistic systems.

Our findings provided more information relative to the strategic co-operation from a group with much coordinated experience. However, strategic alliance is just an adaptive method, while the co-operative aims of carriers are to pursue the maximal profit and to keep running forever. For carriers, the next important issues are how to choose well-matched partners, how to develop the suitable extent of co-operation, and how to assure the success of alliance. Within the same alliance, members may have higher co-operative aims for the future operations, when some agreements of slot exchange or purchase between different groups are still productively in existence. The flexible and appropriate operation model of co-operation actually follows with the change of the shipping markets and the requirement of customers. Several small carriers use slot sharing on particular service routes and co-operate with members of certain strategic alliances for gain their competitive advantages. The contents of future direction in strategic alliances could be focused on the decision co-operation, such as ordering the same types of new fleet and discussing the fleet deployment in future services. The development of pushing and pulling powers between these two ways will be a valuable point for future research.

\section{ACKNOWLEDGEMENTS}

The authors express their sincere gratitude to those professionals from Yang Ming Marine Transport Company, as well as anonymous experts from COSCO, $\mathrm{K}$-Line, and Hanjin for contributing their valuable time and opinions to this study.

\section{REFERENCES}

1. Alix, Y., Slack, B., and Comotis, C., "Alliance or Acquisition? Strategies for Growth in the Container Shipping Industry, the Case of CP Ships," Journal of Transport Geography, Vol. 7, pp. 203-208 (1999).

2. Czinkota, M.R. and Ronkainen, I.A., "A Forecast of Globalization, International Business and Trade: Report from a Delphi Study," Journal of World Business, Vol. 40, pp. 111-123 (2005).

3. Fossey, J., "Birth of the Global Alliance," Containerization International, Oct., pp. 49 (1994).

4. Graham, M.G., "Stability and Competition in Intermodal Container Shipping: Finding A Balance," Maritime Policy and Management, Vol. 25, No. 2, pp. 129-147 (1998).

5. Gupta, U.G. and Clarke, R.E., "Theory and Application of the Delphi Technique: A Bibliography (1975-1994)," Technological Forecasting and Social Changes, Vol. 53, pp. 185-211 (1996).

6. Kadar M., "The Future of Global Strategic Alliances," Containerization International, Apr., pp. 81-85 (1996).

7. Linstone, H.A. and Turoff, M., The Delphi Method: Techniques and Applications, Addison-Wesley, MA, pp. 3-12 (2002).

8. Marchau, V.A.W.J. and Heijden, R.E.C.M., "Policy Aspects of Driver Support Systems Implementation: Results of An International Delphi study," Transport Policy, Vol. 5, pp. 249-258 (1998).

9. Midoro, R. and Pitto, A., "A Critical Evaluation of Strategic Alliances in Liner Shipping," Maritime Policy and Management, Vol. 27, No. 1, pp. 31-40 (2000).

10. Okoli, C. and Pawlowski, S.D., "The Delphi Method as a Research Tool: An Example, Design Considerations and Applications," Information \& Management, Vol. 42, pp. 15-29 (2004).

11. Rimmer, P.J., "Ocean Liner Shipping Services: Corporate Restructuring and Port Selection/Competition," Asia Pacific Viewpoint, Vol. 39, No. 2, pp. 193-208 (1998).

12. Robinson, R., "Asian Hub/Feeder Nets: The Dynamics of Restructuring," Maritime Policy and Management, Vol. 25, No. 1, pp. 21-40 (1998).

13. Ryan, D.A.J., "Strategic Alliances and Their Impacts on the Container Shipping Industry," Master Thesis, Concordia University, Canada (2001).

14. Ryoo, D.K. and Thanopoulou, H.A., "Liner Alliances in the Globalization Era: A Strategic Tool for Asian Container Carriers," Maritime Policy and Management, Vol. 26, No. 4, pp. 349-367 (1999).

15. Schmidt, R.C., "Managing Delphi Surveys Using Nonparametric Statistical Techniques," Decision Sciences, Vol. 28, No. 3, pp. 763-774 (1997).

16. Slack, B., Comtois, C., and McCalla, R., "Strategic Alliances in the Container Shipping Industry: A Global Perspective," Maritime Policy and Management, Vol. 29, No. 1, pp. 65-76 (2002).

17. Still, B.G., May, A.D., and Bristow, A.L., "The Assessment of Transport Impacts on Land Use: Practical Uses in Strategic Planning," Transport Policy, Vol. 6, pp. 8398 (1999).

18. Thanopoulou, H.A., Ryoo, D.K., and Lee, T.-W., "Korean Liner Shipping in the Era of Global Alliances," Maritime Policy and Management, Vol. 26, No. 3, pp. 209-229 (1999).

19. Tsai, M.-C. and Su, C.-H., "Political Risk Assessment of Five East Asian Ports-The Viewpoints of Global Carriers," Marine Policy, Vol. 29, pp. 291298 (2005). 


\section{APPENDIX}

Part I: What are the key reasons for strategic co-operation in your esteem shipping company? Please identify the reasons and qualify these reasons in terms of importance on a scale from 1 to $3(1=$ not important at all; $2=$ important; 3 = very important).

\begin{tabular}{|c|c|c|c|c|c|c|c|}
\hline & \multirow[t]{2}{*}{ Question } & \multicolumn{3}{|c|}{$\begin{array}{l}\text { Result of } \\
1^{\text {st }} \text { survey }\end{array}$} & \multicolumn{3}{|c|}{$\begin{array}{l}\text { Result of } \\
2^{\text {nd }} \text { survey }\end{array}$} \\
\hline & & 1 & 2 & 3 & 1 & 2 & 3 \\
\hline 1 & Reduce capital cost of purchasing or supplying ships & & & & & & \\
\hline 2 & Share the risks of providing new liner services & & & & & & \\
\hline 3 & Increase capital utilization of ships, container equipment $\&$ terminal facility & & & & & & \\
\hline 4 & Conform to shipping policy of foreign government & & & & & & \\
\hline 5 & Extend service coverage & & & & & & \\
\hline 6 & Provide total container logistics services & & & & & & \\
\hline 7 & Provide more frequent sailing services & & & & & & \\
\hline 8 & Faster entry to new trade routes & & & & & & \\
\hline 9 & Rationalize service routes & & & & & & \\
\hline 10 & Increase market share & & & & & & \\
\hline 11 & Benefit from economies of scale to reduce cost & & & & & & \\
\hline 12 & Provide faster transit service & & & & & & \\
\hline 13 & Gain the skill or know-how in liner shipping industry & & & & & & \\
\hline 14 & Maximize operational synergy & & & & & & \\
\hline 15 & Stabilize freight rate & & & & & & \\
\hline 16 & Maximize financial synergy & & & & & & \\
\hline 17 & Link into partner's established marketing network & & & & & & \\
\hline 18 & Limit external competition & & & & & & \\
\hline 19 & Reduce financial burden on equipment investment & & & & & & \\
\hline 20 & Conform to shipping policy of national government & & & & & & \\
\hline
\end{tabular}

Part II: Based on your experienced knowledge in liner shipping industry, is there any possible disadvantage may be incurred during strategic co-operation? Please kindly identify and qualify these possible disadvantages in terms of degree on a scale from 1 to 3 ( 1 = not disadvantageous at all; 2 = disadvantageous; 3 = very disadvantageous).

\begin{tabular}{|c|c|c|c|c|c|c|c|}
\hline & \multirow[t]{2}{*}{ Question } & \multicolumn{3}{|c|}{$\begin{array}{l}\text { Result of } \\
1^{\text {st }} \text { survey }\end{array}$} & \multicolumn{3}{|c|}{$\begin{array}{l}\text { Result of } \\
2^{\text {nd }} \text { survey }\end{array}$} \\
\hline & & & 2 & 3 & & 2 & 3 \\
\hline 1 & Market competition between co-operating partners & & & & & & \\
\hline 2 & Inherent instability between co-operating partners & & & & & & \\
\hline 3 & Worrying to be merged or acquired by co-operating partners & & & & & & \\
\hline 4 & Inefficient decision-making procedure within co-operation partners & & & & & & \\
\hline 5 & Cost for leaving from a co-operation & & & & & & \\
\hline 6 & Infeasibility to co-operate due to partners' compatibility & & & & & & \\
\hline 7 & $\begin{array}{l}\text { The internal conflict among management level due to the different understanding to join } \\
\text { a strategic co-operation }\end{array}$ & & & & & & \\
\hline 8 & Worrying to lose own company’s individual decision making capability & & & & & & \\
\hline 9 & Market reputation may be affected negatively due to co-operate with poor-reputed partner & & & & & & \\
\hline 10 & The conflict of interest on terminal or inland facility between co-operating partners & & & & & & \\
\hline
\end{tabular}


Part III: What are the key reasons for successful co-operation in your esteem shipping company? Please identify the reasons and qualify these reasons in terms of importance on a scale from 1 to $3(1=$ not important at all; $2=$ important; 3 = very important).

\begin{tabular}{|c|c|c|c|c|c|c|c|}
\hline & \multirow[t]{2}{*}{ Question } & \multicolumn{3}{|c|}{$\begin{array}{l}\text { Result of } \\
1^{\text {st }} \text { survey }\end{array}$} & \multicolumn{3}{|c|}{$\begin{array}{l}\text { Result of } \\
2^{\text {nd }} \text { survey }\end{array}$} \\
\hline & & 1 & 2 & 3 & 1 & 2 & 3 \\
\hline 1 & Continuous mutual commitment of facilities (ships, equipment) & & & & & & \\
\hline 2 & Mutual agreement on co-operation objectives & & & & & & \\
\hline 3 & Good understanding by all parties of competition and marketplace & & & & & & \\
\hline 4 & Continuous mutual commitment of finance & & & & & & \\
\hline 5 & Flexibility of co-operation & & & & & & \\
\hline 6 & Good interpeopleal relations between partner & & & & & & \\
\hline 7 & Compatible decision-making processes & & & & & & \\
\hline 8 & Sharing of integrated computer systems/EDI & & & & & & \\
\hline 9 & Open communication between the parties & & & & & & \\
\hline 10 & Continuous CEO direction and involvement & & & & & & \\
\hline 11 & Partner compatibility (in particular of company's culture) & & & & & & \\
\hline 12 & Step by step to increase co-operation goal from minor to major gradually & & & & & & \\
\hline 13 & The number $\&$ size of partners & & & & & & \\
\hline 14 & A reasonable \& practicable cooperating rule for following up & & & & & & \\
\hline 15 & Mutual trust between all partners & & & & & & \\
\hline
\end{tabular}

Part IV: Based on your experienced knowledge in liner shipping, please generally predict a middle-term future (upto 2010) of global liner shipping industry and qualify the prediction in terms of agreement on a scale from 1 to 3 (1 = disagreed; 2 = agreed; 3 = totally agreed $)$.

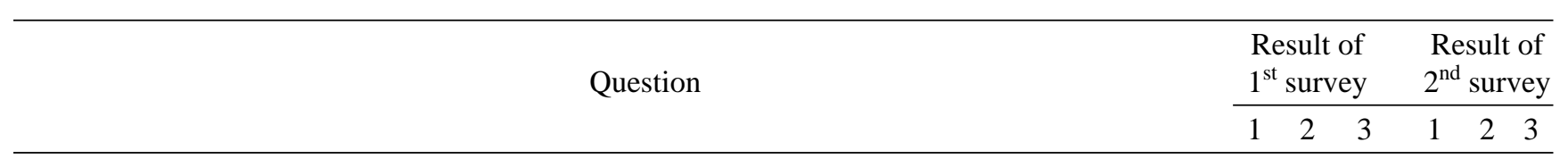

1 The strategic co-operation in global liner shipping will be continually developing to enable the carrier responding the rapid change of liner shipping industry

2 The strategic co-operation among liner shipping carriers will become more important than before as today's liner shipping industry is hardly to survive by individual alone

3 Compared with 1960 1990 the consortia was mainly dominated by European carriers, the strategic alliance in 1990s was apparently dominated by Asian carriers thus the Asian carriers may play a more important role in today's global liner shipping industry

4 The purpose \& model of strategic co-operation will become more \& more flexible to enable the liner carrier to meet the requirement of quick-changing shipping environment

5 Huger \& huger container vessels are going to be deployed in East-West trades \& the replaced vessels will be shifted to North-South or regional routes thus consequently the liner shipping industry in any trades will become more competitive than before

6 Total logistics solution (One-Stop-Shopping) will be the main stream of global shipper's requirement and the liner carrier's strategic co-operations on terminal and inland assets will be increased

7 The China's strong growing-economy is boosting the world's trades dramatically thus gives a opportunity to Asian liner carriers on the ground of geographical advantage

8 To use the chartered vessels instead of own purchasing vessels will be increased in order to reduce both the capital expenditure \& risk

9 Compared with merger \& acquiring, the strategic alliance in global liner shipping is more economic, flexible and feasible to global liner carrier

10 In addition to major East-west routes, the Intra Asian regional container trades is growing up significantly 